\title{
Assessment of some trace heavy metals and radioactivity concentration in drinking water of Saudi Arabia
}

\author{
Rafat M. Amin \\ Physics department, Faculty of Science, Beni Suef University, Egypt \\ E-mail: rafatamin@yahoo.com
}

\begin{abstract}
Concentration of trace elements and natural gross radioactivity were measured in the drinking water in Jizan region (Saudi Arabia). A preliminary study on trace elements ( $\mathrm{n}, \mathrm{Fe}, \mathrm{Mn}, \mathrm{Ni}, \mathrm{Cu}, \mathrm{Cr}, \mathrm{Co}, \mathrm{Se}, \mathrm{Sr}, \mathrm{V}, \mathrm{Ti}, \mathrm{Mo}, \mathrm{Hg}, \mathrm{Cd}, \mathrm{Ba}$, $\mathrm{As}, \mathrm{Al}$ and $\mathrm{Pb}$ ) concentrations and natural radioactivity related to gross- $\alpha$ and gross- $\beta$ radiations in the drinking water were determined. The obtained results showed that, in general, the trace elements concentrations in water did not exceed WHO [1], and GSO [2] guidelines. Generally, heavy metals concentration of the drinking water were found to be in the sequence of $\mathrm{Sr}>\mathrm{Ti}>\mathrm{Fe}>\mathrm{Al}>\mathrm{Zn}>\mathrm{Ba}>\mathrm{As}>\mathrm{Cu}>\mathrm{Mo}>\mathrm{Ni}>\mathrm{Cr}>\mathrm{Co}>\mathrm{Se}>\mathrm{Hg}>\mathrm{Mn}$, respectively. The results of this study indicated that a general absence of serious pollution in the drinking water used in this region. The results obtained from the radioactivity determination indicate that the drinking water radioactivity concentration of gross- $\alpha$ and gross- $\beta$ were ranging from $0.06 \pm 0.001$ to $0.45 \pm 0.03 \mathrm{~Bq} / \mathrm{l}$ and from $0.05 \pm 0.006$ to $2.95 \pm 0.23 \mathrm{~Bq} / \mathrm{l}$, respectively. The gross alpha values were found to fall below the GSO and WHO recommended MCL of $0.5 \mathrm{~Bq} / \mathrm{l}$ while the gross beta values in two samples only exceeds the MCL value of $1 \mathrm{~Bq} / \mathrm{l}$, respectively.
\end{abstract}

Keywords: gross alpha, gross beta, heavy elements, Saudi Arabia

\section{1- INTRODUCTION}

Water is very important for our life. It forms 50 to $60 \%$ in weight of our body and play an active role in all the vital processes of our body. Therefore, water must be free from organisms that are capable of causing disease and from minerals and organic substances that could produce adverse physiological effects [3].

Environmental contaminant is a major problem being faced by the society. One of the many pollutants in the environment is heavy metals. The presence of heavy metals in atmosphere is due to a natural and an anthropogenic origin. Heavy metals are among the most toxic pollutants present in marine, groundwater and industrial wastewater. The source of heavy metals in environment, and more specifically in water systems has been attributed primarily to man made sources, such as agricultural activities and stack emissions from industrial sources. While the toxic metal compounds turned back to earth arrive to surface waters with river, rain and snow waters, they may be mixed to groundwater by filtering from soil.

Trace elements have important effects in the life processes. The most activities have concentrated some of heavy metals in certain areas up to the dangerous levels of living organism [4]. Trace elements such as lead, mercury, arsenic, copper, zinc and cadmium are toxic for the humans even at very low level of intake and accumulated in living organisms and produce disease and disorders.

Radioactivity in waters is mainly originated from radioactive elements in the earth's crust. Surface water and especially ground water play an important role in the migration and distribution of these elements in the earth's crust [5]. Concentrations of natural radionuclides in water could be related to the physicochemical conditions and the geological formation of the area.

Natural radioactivity arises mainly from the primordial radionuclides, such as ${ }^{40} \mathrm{~K}$, and the radionuclides from the ${ }^{238} \mathrm{U}$ and ${ }^{232}$ Th and their decay products, which are present at trace levels in all ground formations [6].

The monitoring of drinking water quality is necessary in order to detect pollution and to prevent use of contaminated drinking water for public water supply.

Many standards, both international and national, are available now. These standards recommend maximum permissible limits on several water quality parameters in order to avoid any adverse effect on the health of the population consuming the water.

Saudi Arabia is a desert country with no permanent rivers or lakes and very little rainfall. Water is scarce and extremely valuable, and with the country's rapid growth, the demand for water is increasing. Aquifers are a major source of water in Saudi Arabia. They are vast underground reservoirs of water. In the 1970s, the government undertook a major effort to locate and map such aquifers and estimate their capacity. As a result, it was able to drill tens of thousands of deep tube wells in the most promising areas for both urban and agricultural use.

Many research studies were carried out on the quality of drinking water that consumed in Saudi Arabia at different localities [7-20].

In Jizan, which is located in Southwestern of Saudi Arabia, there are many wells scattered throughout the region are used as the source of drinking water. As a consequence, it is of importance to investigate the state and quality of waters derived from these wells, in addition to the bottle water come from different regions. 
The main objectives of this study are to evaluate the drinking water quality in this area and examine their compliance with local and international standards. The knowledge of concentrations and distributions of the heavy metals and gross-alpha and gross-beta radioactivity in water samples are of interest since it provides useful information in the monitoring of environmental contaminations [21].

\section{2- METHDOLOGY}

Waters have been analyzed at Medical research center Jizan, for 18 elements (Al, As, Ba, Cd, Co, Cr, Cu, Fe, $\mathrm{Hg}, \mathrm{Mn}$, $\mathrm{Mo}, \mathrm{Ni}, \mathrm{Pb}, \mathrm{Se}, \mathrm{Sr}, \mathrm{Ti}, \mathrm{V}, \mathrm{Zn}$, in addition several parameters such as $\mathrm{pH}$ and total dissolved solids are determined.

Eleven brands of plastic bottled water were obtained randomly from 3 supermarkets in Jizan, Saudi Arabia. Three bottles from each brand, each with a different batch number and date of bottling, were purchased. 10 treated drinking groundwater from commercial stations distributed throughout the region. Seven samples from tap water that come from desalinated water plants but most people don't use in drinking water but in other household purposes.

\subsection{Chemistry}

Samples were collected and stored in PET (polyethylene terephthalate) bottles ( $0.5 \mathrm{~L}$ ) with PET caps completely filled, which were previously soaked in $10 \%$ nitric acid and thoroughly rinsed with deionized distilled water. The samples for heavy metals analyses were acidified to $\mathrm{pH} 2$ with A.R. grade nitric acid in order to minimize the absorption of metals into the wall of the containers and stored approximately at $4{ }^{\circ} \mathrm{C}$.

Measurements of trace elements drinking waters were done by ICP-MS in addition $\mathrm{pH}$ and TDS of water were also determined

The $\mathrm{pH}$ of water samples was determined using a pH meter (CG 817) whereas the total soluble salts were measured using an electrical conductivity (EC) meter (EC) in dS/m at 25 WC (Test kit Model 1500-20, Cole and Parmer)

ICP-MS are by far the most common type of plasma sources used in today's commercial ICP Optical Emission Spectrometry (OES) and ICP-MS instrumentation. In ICP, the first step that takes place is the desolvation of the droplet with the water molecules stripped away; it then becomes a solid particle. As the sample moves further into the plasma, the solid particle changes first into a gaseous form and then into a ground-state atom. The final process of conversion of an atom to an ion is achieved mainly by collisions of energetic argon electrons with the ground state atom. The ion then emerges from the plasma and is directed into the interface on the mass spectrometer. The measurement determines the parts per million (ppm) of elements in the sample.

\subsection{Radioactivity}

The gas-flow-proportional counter (Eurisys Measure- IN20) eight channel Alpha and Beta counter was used for the measurements of the gross alpha and beta in the portable water samples. Each counter channel has a window thickness of $450 \mu \mathrm{g} / \mathrm{cm}^{3}$ and diameter of $0.06 \mathrm{~m}$. The counting gas is an argon-methane mixture in the ratio of $90 \%$ to $10 \%$. The counting system incorporates an anti-coincident guard counter used to eliminate interference from high energy cosmic radiation that would enter the measuring environment. The chambers are covered with $0.1 \mathrm{~m}$ lead thick to prevent part of ambient gamma rays from entering the measuring environment.

For signal processing purpose, the system is connected to a microprocessor loaded with a spread sheet programme (Quarttro-Pro) and graphic programme (Multiplan). The system can be operated at a bias voltage $\sim 1100 \mathrm{~V}$ where only alpha particles are detected, referred to as 'alpha only' mode. If the bias voltage is increased to $\sim 1650 \mathrm{~V}$ with same gas, the counter will respond to both alpha and beta particles simultaneously. Operation at this higher voltage is referred to as 'simultaneous' or 'alpha + beta' mode. The alpha standards were ${ }^{239} \mathrm{Pu}$ whose half life is $24,200 \mathrm{y}$. The energy of alpha decay is $5.245 \mathrm{MeV}$. The beta standards were ${ }^{90} \mathrm{Sr}$ whose half life is 28.8 y and beta decay energy is $0.546 \mathrm{MeV}$. These standards were certified by CERCA LEA Laboratories in France with certificate numbers CT001/1285/001920-1927 and CT 1271/00/1778-1783, respectively. Plateau test was run with the manufacturer's calibration standards $\left({ }^{239} \mathrm{Pu}\right.$ and ${ }^{90} \mathrm{Sr}$ ) whose activities ranges from 133.4 to $185.7 \mathrm{~Bq}$ and 98.4 to $113.8 \mathrm{~Bq}$, respectively in all the three operating modes. This test was run for 1800 s for five cycles.

Measured Detector Efficiency: The results of the operational efficiencies of the different channels of the detector in alpha only and beta only modes are presented in Table 1 . The result indicated an average efficiency of $34.42 \pm 0.92 \%$ for the alpha

counts in alpha-only mode and $53.88 \pm 0.76 \%$ for the beta counts in beta-only mode. These are good efficiency values for this type of counting system.

\section{Sample collection and analysis}

Samples were collected in clean $0.5 \mathrm{~L}$ polyethene containers with tight covers. The containers were rinsed thoroughly with the water. The samples were acidified by adding 20 milliliter $(\mathrm{ml})$ of $\mathrm{IN} \mathrm{HNO}_{3}$ to minimize the lost of radiation to the containers wall. The samples were then analyzed.

\section{Estimation of committed effective dose}

Radionuclide may reach the gastrointestinal tract directly by ingestion or indirectly by transfer from the respiratory tract. From small intestine the radionuclide can be absorbed to the body fluids. 
On average, adults are considered to consume two and half liters of water per day which corresponds to $913 \mathrm{~L} / \mathrm{y}$. The committed quantities, because of small effective half-lives, are practically realized within one year after intake [22]. In this work, the effective dose over one year was calculated using the following relation.

$$
E=I A C \times 365
$$

Where $I$ is the daily water consumption in I/day, $A$ is the activity/l; $C$ is a dose conversion factor in Sv/Bq. Dose conversion factors used to calculate the internal radiation exposure by ingestion of radionuclide is $2.8 \times 10^{-7}$ [23].

Table 1. Channel Efficiencies for different modes of measurement

\begin{tabular}{|l|c|c|}
\hline Detector Channel No & Eff. alpha only mode \% & Eff. beta only mode \% \\
\hline 01 & $34.22 \pm 0.95$ & $56.48 \pm 0.41$ \\
\hline 02 & $34.49 \pm 0.90$ & $55.89 \pm 0.88$ \\
\hline 03 & $34.3 \pm 0.91$ & $56.33 \pm 0.63$ \\
\hline 04 & $34.76 \pm 0.87$ & $50.20 \pm 0.87$ \\
\hline 05 & $34.2 \pm 0.95$ & $52.44 \pm 0.81$ \\
\hline 06 & $34.09 \pm 0.90$ & $54.48 \pm 0.84$ \\
\hline 07 & $34.79 \pm 0.99$ & $53.58 \pm 0.79$ \\
\hline 08 & $34.53 \pm 0.90$ & $51.67 \pm 0.90$ \\
\hline Average & $34.42 \pm 0.92$ & $53.88 \pm 0.76$ \\
\hline
\end{tabular}

\section{3- RESULTS AND DISCUSSION}

\subsection{Chemical Characteristics}

pH value: The $\mathrm{pH}$ of the bottled waters varied between 6.7 and 7.8 whereas that of treated waters was in the range of $7-$ 8.1 and for tap water 7.1-8.3. The WHO guidelines and the GSO standards recommended 6.5-8.5 pH values for waters for drinking purposes (Table 2). These limits were respected in all types of waters.

\section{Total dissolved solids (TDS)}

The bottled waters TDS values varied between 110 and $175 \mathrm{mg} / \mathrm{l}$ whereas those of the treated ranged from 127 to 187 $\mathrm{mg} / \mathrm{l}$ and from 125 to $210 \mathrm{mg} / \mathrm{l}$ for tap waters. However, dissolved solids in all samples were very much within the WHO and GSO drinking water standards (Table 2).

\section{Trace metals}

A total of 18 trace elements were analyzed and the results are shown in Table 2 whereas WHO and GSO standards have been presented in Table 3. The average values of the trace elements for all samples are given in Table 2.

Aluminum (Al): The Al level varied between 22 to $148 \mu \mathrm{g} / \mathrm{l}$ in the bottled samples and ranged between 78 and $188 \mu \mathrm{g} / \mathrm{ln}$ the treated waters while from 55 to $110 \mu \mathrm{g} / \mathrm{l}$ for tap waters. None of the types had values that exceeded the GSO (100 $\mu \mathrm{g} / \mathrm{l})$ and WHO guidelines of $200 \mu \mathrm{g} / \mathrm{l}$.

Barium (Ba): In all water samples, the concentration values ranged between 0.151 and $12.07 \mu \mathrm{g} / \mathrm{l}$. None of the water samples had values that exceeded the maximum GSO and WHO limits $700 \mu \mathrm{g} / \mathrm{l}$.

Table 2: Summary of the whole parameters measured in the Saudi drinking waters

\begin{tabular}{|c|c|c|c|c|c|c|c|c|c|}
\hline \multirow{2}{*}{ Element } & \multicolumn{3}{|c|}{ Bottled } & \multicolumn{3}{|c|}{ Tap } & \multicolumn{3}{|c|}{ Treated } \\
\hline & Min & Max & Mean & Min & Max & Mean & Min & Max & Mean \\
\hline $\mathrm{pH}$ & 6.7 & 7.8 & 7.3 & 7.1 & 8.3 & 7.5 & 7.0 & 8.1 & 7.6 \\
\hline TDS & 110 & 175 & 127 & 125 & 210 & 145 & 127 & 187 & 139 \\
\hline $\mathrm{Al}$ & 22 & 148 & 98 & 55 & 110 & 83 & 78 & 188 & 124 \\
\hline As & 0.235 & 4.08 & 1.51 & 0.45 & 3.65 & 1.87 & 0.788 & 2.878 & 1.585 \\
\hline $\mathrm{Ba}$ & 0.151 & 4.723 & 0.934 & 0.26 & 2.56 & 1.59 & 1.733 & 12.07 & 5.305 \\
\hline $\mathrm{Cd}$ & \multicolumn{3}{|c|}{ ND } & \multicolumn{3}{|c|}{ ND } & \multicolumn{3}{|c|}{ ND } \\
\hline Co & 0.020 & 3.017 & 0.336 & 0.046 & 0.872 & 0.324 & 0.062 & 0.253 & 0.143 \\
\hline $\mathrm{Cr}$ & \multicolumn{3}{|c|}{ ND } & \multicolumn{3}{|c|}{ ND } & 0.025 & 1.128 & 0.274 \\
\hline
\end{tabular}




\begin{tabular}{|c|c|c|c|c|c|c|c|c|c|}
\hline $\mathrm{Cu}$ & 0.208 & 1.935 & 0.845 & 0.322 & 3.35 & 2.087 & 0.272 & 8.15 & 1.933 \\
\hline $\mathrm{Fe}$ & 0.89 & 14.56 & 7.56 & 1.36 & 19.5 & 12.8 & 3.56 & 22.7 & 16.9 \\
\hline $\mathrm{Hg}$ & 0.007 & 0.083 & 0.026 & 0.017 & 0.17 & 0.036 & 0.017 & 0.25 & 0.098 \\
\hline $\mathrm{Mn}$ & 0.001 & 0.129 & 0.023 & \multicolumn{3}{|c|}{$\mathrm{ND}$} & 0.011 & 0.069 & 0.024 \\
\hline Mo & 0.032 & 0.641 & 0.075 & 0.062 & 1.28 & 0.404 & 0.008 & 1.35 & 0.50 \\
\hline $\mathrm{Ni}$ & 0.152 & 1.032 & 0.301 & \multicolumn{3}{|c|}{ ND } & \multicolumn{3}{|c|}{$\mathrm{ND}$} \\
\hline $\mathrm{Pb}$ & \multicolumn{3}{|c|}{ ND } & \multicolumn{3}{|c|}{$\mathrm{ND}$} & \multicolumn{3}{|c|}{ ND } \\
\hline Se & - & - & 0.0679 & \multicolumn{3}{|c|}{$\mathrm{ND}$} & & . & 0.114 \\
\hline $\mathrm{Sr}$ & 1.104 & 199.4 & 66.77 & 10.12 & 55.3 & 33.9 & 12.36 & 364.2 & 164.2 \\
\hline $\mathrm{Ti}$ & 11.64 & 68.64 & 24.93 & 1.23 & 25.12 & 6.853 & 13.15 & 43.83 & 25.96 \\
\hline V & \multicolumn{3}{|c|}{ ND } & \multicolumn{3}{|c|}{ ND } & \multicolumn{3}{|c|}{$\mathrm{ND}$} \\
\hline $\mathrm{Zn}$ & \multicolumn{3}{|c|}{ ND } & 0.82 & 11.36 & 1.13 & 0.561 & 19.53 & 9.09 \\
\hline
\end{tabular}

Chromium (Cr): The solubility of $\mathrm{Cr}$ in most water is low; however, with decreasing $\mathrm{pH}$ the solubility increases. None of the bottled waters brands had $\mathrm{Cr}$ above the detection limit of $0.08 \mu \mathrm{g} / \mathrm{l}$ whereas the treated waters had values ranged from 0.025 to $1.128 \mu \mathrm{g} / \mathrm{l}$. All $\mathrm{Cr}$ levels were much below the maximum concentrations of $50 \mu \mathrm{g} / \mathrm{l}$ allowed by GSO and WHO standards.

Lead $(\mathrm{Pb})$ : None of the water samples were found to contain Lead in concentrations above the detection limit of $1.0 \mu \mathrm{g} / \mathrm{l}$. None of the samples had significantly high $\mathrm{Pb}$ concentrations.

Manganese (Mn) : Manganese was found below the ICP detection limit in $81 \%$ of the bottled waters and $40 \%$ of the treated waters. However, all values were much below the WHO maximum limits of $400 \mu \mathrm{g} / \mathrm{l}$.

Cobalt (Co): The minimum and maximum Co concentrations for bottled waters were 0.02 and $3.017 \mu \mathrm{g} / \mathrm{l}$, respectively. The treated waters had values between 0.062 and $0.253 \mu \mathrm{g} / \mathrm{l}$ while vary from 0.046 to $0.872 \mu \mathrm{g} / \mathrm{l}$ for tap water. According to GSO, as well as other international organizations, there is no maximum admissible concentration for cobalt.

Copper $(\mathrm{Cu})$ : The concentration of $\mathrm{Cu}$ in bottled water varied from 0.208 to $1.935 \mu \mathrm{g} / \mathrm{l}$ and from 0.27 to $8.15 \mu \mathrm{g} / \mathrm{l}$ for treated waters while from 0.332 to $3.35 \mu \mathrm{g} / \mathrm{l}$ for tap water. According to GSO, Cu concentration should not exceed 1000 $\mu \mathrm{g} / \mathrm{l}$.

Iron (Fe): Iron was present in all samples with levels ranging between minimum and $22.7 \mu \mathrm{g} / \mathrm{l}$. only three bottled and 1 treated samples had concentrations below the detection limit $(0.08 \mu \mathrm{g} / \mathrm{l})$. None of the samples had concentrations above the GSO and WHO limit of $300 \mu \mathrm{g} / \mathrm{l}$.

Molybdenum (Mo): The Mo concentration in all samples in the range of minimum to $1.35 \mu \mathrm{g} / \mathrm{l}$. According to GSO and WHO standards, Mo concentration should not exceed $70 \mu \mathrm{g} / \mathrm{l}$.

Selenium (Se): only one treated sample and one bottle sample were found to contain Se concentration. None of the samples exceeded the maximum limit of $10 \mu \mathrm{g} / \mathrm{l}$ set by GSO and WHO standards.

Zinc (Zn): Zinc was found below the ICP detection limit in all bottled water. The obtained value in the treated water was found to range between 0.561 to $19.53 \mu \mathrm{g} / \mathrm{l}$. According to WHO, Zn concentration should not exceed $3000 \mu \mathrm{g} / \mathrm{l}$.

Titanium (Ti): None of the water samples were found to contain Titanium in concentrations above the detection limit ICP. According to GSO, as well as other international organizations, there is no maximum admissible concentration for titanium.

Nickel (Ni): None of the bottled waters were found to contain Nickel in concentrations above the detection limit. Only $36 \%$ from the treated water had $\mathrm{Ni}$ above the ICP detection limit. According to WHO, Ni concentration should not exceed 70 $\mu \mathrm{g} / \mathrm{l}$.

Vanadium (V): Although there are no data on $\mathrm{V}$ oral toxicity, none of the water samples were found had $\mathrm{V}$ values above the ICP detection limit.

Cadmium (Cd): Humans are exposed to $\mathrm{Cd}$ as a result of its ingestion from food or water, with the major contribution coming from food. The Cd level in the bottled water was found below the ICP detection limit while one treated water sample was found above the detection limit. According to GSO and WHO limits, Cd concentration should not exceed 3 $\mu \mathrm{g} / \mathrm{l}$.

Mercury $(\mathbf{H g})$ : Mercury is one of the earth's rarest elements. In its natural state it occurs mainly in combination with sulfur. Only $17 \%$ of the bottled water while $20 \%$ from the treated waters were found values below the ICP detection limit. The values ranged from BDL to $0.25 \mu \mathrm{g} / \mathrm{l}$. According to $\mathrm{WHO}, \mathrm{Hg}$ concentration should not exceed $6 \mu \mathrm{g} / \mathrm{l}$.

Table 3: WHO guideline values and GSO normative limits for drinking water $(\mu \mathrm{g} / \mathrm{l})$. 


\begin{tabular}{|l|c|c|}
\hline Parameter & GSO, 2009 & WHO, 2011 \\
\hline $\mathrm{pH}$ & $6.5-8.5$ & $6.5-8.5$ \\
\hline $\mathrm{TDS}$ & $100-600 \mathrm{mg} / \mathrm{l}$ & $1000 \mathrm{mg} / \mathrm{l}$ \\
\hline $\mathrm{Al}(\mu \mathrm{g} / \mathrm{L})$ & 100 & 200 \\
\hline $\mathrm{AS}$ & 10 & 10 \\
\hline $\mathrm{Ba}$ & 700 & 700 \\
\hline $\mathrm{Cd}$ & 3 & 3 \\
\hline $\mathrm{Co}$ & - & - \\
\hline $\mathrm{Cr}$ & 50 & 50 \\
\hline $\mathrm{Cu}$ & 1000 & 2000 \\
\hline $\mathrm{Fe}$ & 300 & 300 \\
\hline $\mathrm{Hg}$ & 1 & 6 \\
\hline $\mathrm{Mn}$ & 10 & 400 \\
\hline $\mathrm{Mo}$ & 70 & 70 \\
\hline $\mathrm{Ni}$ & 20 & 70 \\
\hline $\mathrm{Pb}$ & 20 & 10 \\
\hline $\mathrm{Se}$ & 10 & 10 \\
\hline $\mathrm{Sr}$ & - & - \\
\hline $\mathrm{Zn}$ & - & 3000 \\
\hline $\mathrm{V}$ & 100 & - \\
\hline $\mathrm{Ti}$ & - & - \\
\hline
\end{tabular}

Arsenic (As): Arsenic is widely and evenly distributed in solids and water in low concentrations. Generally, the earth crust contains an average of $2 \mathrm{mg} \mathrm{kg}^{-1}$ or less of arsenic. Most of the arsenic in water occurs naturally from erosion of rock surfaces. Where arsenic concentrations are abnormally high, the source is usually industrial. Arsenic (As) concentration in all samples was ranged between 0.235 to $4.08 \mu \mathrm{g} / \mathrm{l}$. According to GSO and WHO, Arsenic concentration should not exceed $10 \mu \mathrm{g} / \mathrm{l}$.

Strontium (Sr): The Sr in naturally occurring element and the guideline value $(4200 \mu \mathrm{g} / \mathrm{L})$ for $\mathrm{Sr}$ is very high, compared to all trace elements.

The range of $\mathrm{Sr}$ in bottled water varied from 1.104 to $199.4 \mu \mathrm{g} / \mathrm{l}, 12.36$ to $364.3 \mu \mathrm{g} / \mathrm{l}$ in treated water while from 10.12 to $55.3 \mathrm{\mu g} / \mathrm{l}$ in tap water. However, the recorded values in all three water types did not exceed the guideline value.

Results show that the drinking water quality in Jizan generally meets the international standards. Toxic elements such as $\mathrm{Cd}, \mathrm{Cr}, \mathrm{Ni}, \mathrm{V}$, and $\mathrm{Pb}$ were either present in minute quantities or not detectable at all, and were below the WHO and GSO guideline values. As such, human consumption of treated drinking water or bottled drinking water in Jizan should not lead to adverse health effects typically associated with these elements. The levels of trace elements in the bottled and treated drinking water samples do not suggest any implications for human health, based on international/national guideline values (Table 3).

It is noteworthy that none of the measured elements in drinking water samples in this study exceeded the international guideline values. Therefore, one can conclude that the drinking water quality in Jizan region complies with international guidelines.

\subsection{Radioactivity}

From the laboratory results of the gross alpha and gross beta activities, indicate the gross alpha activity ranges from $0.06 \pm 0.001 \mathrm{~Bq} / \mathrm{l}-0.45 \pm 0.03 \mathrm{~Bq} / \mathrm{l}$, with an average of $0.19 \pm 0.033 \mathrm{~Bq} / \mathrm{l}$. The gross beta activity ranges from $0.05 \pm 0.006$ $\mathrm{Bq} / \mathrm{l}-2.95 \pm 0.23 \mathrm{~Bq} / \mathrm{l}$, with an average of $0.54 \pm 0.05 \mathrm{~Bq} / \mathrm{l}$ (Fig. 1). However, a comparison to the world standard values of the values obtained from the laboratory results for the gross alpha and beta activities are presented. 


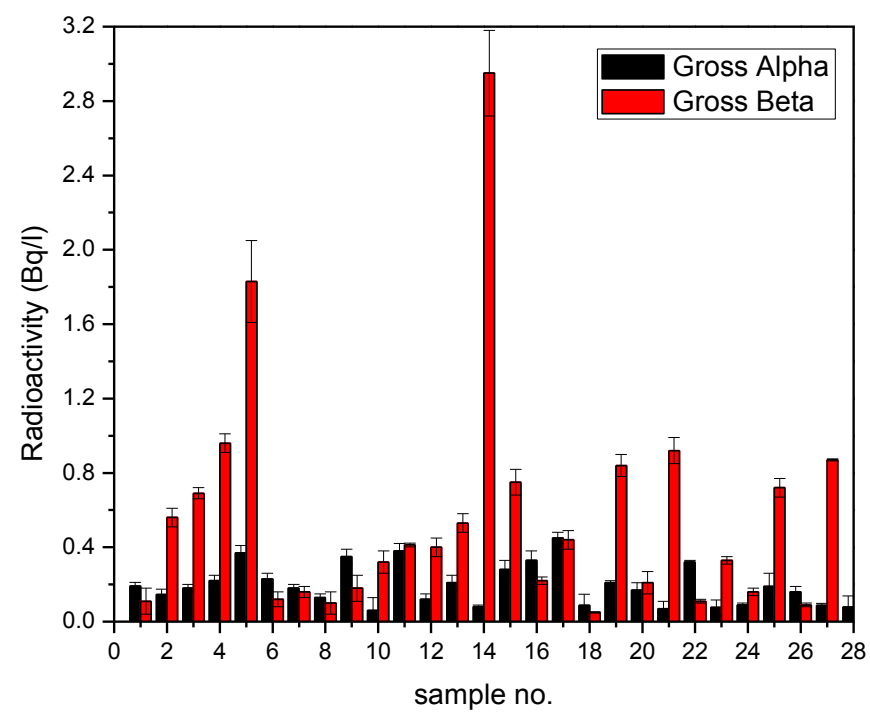

Fig 1: The gross alpha and beta activities in portable water

The study results reveals that; all the values of the gross alpha activity concentrations are within the recommended upper limit value of $0.5 \mathrm{~Bq} / \mathrm{l}$ while all the values of the gross beta activity concentrations are lower than recommended upper limit value of $1 \mathrm{~Bq} / \mathrm{l}$ except two samples. Hence, the drinking water of the study area (Jizan) is radioactively safe to use. The gross alpha and beta activity concentrations obtained compare well with other values reported in literatures as presented in Table 4

Table 4. Comparison of the gross $\alpha$ and $\beta$ concentrations determined in portable drinking water samples with those reported in other countries

\begin{tabular}{|l|c|c|c|}
\hline Country & Gross alpha $(\mathrm{mBq} / \mathrm{l})$ & Gross Beta $(\mathrm{mBq} / \mathrm{l})$ & Reference \\
\hline Jordan & $29-3146$ & $0-5014$ & {$[24]$} \\
\hline Nigeria & $216-1299$ & $64-582$ & {$[25]$} \\
\hline Greece & 82 & 283 & {$[26]$} \\
\hline Brazil & $1-400$ & $120-860$ & {$[27]$} \\
\hline Nigeria & $5.8-174$ & $14.7-222.5$ & {$[28]$} \\
\hline Turkey & 192 & 579 & {$[29]$} \\
\hline Saudi Arabia & 194 & 540 & This study \\
\hline
\end{tabular}

The estimated committed effective dose values are presented in Table 5 . The committed effective dose due to the gross alpha activity concentrations within Jizan region ranged from $0.015 \mathrm{mSv} / \mathrm{y}$ to $0.1 \mathrm{mSv} / \mathrm{y}$ with a mean value of $0.05 \pm 0.008$ $\mathrm{mSv} / \mathrm{y}(0.015-0.097,0.018-0.1$ and $0.019-0.08 \mathrm{mSv} / \mathrm{y})$ for bottled, treated and tap waters, respectively. The estimated mean committed effective dose are within $0.1 \mathrm{mSv} / \mathrm{y}$ reference dose level [30]. This study therefore shows that the consumption of drinking water does not pose any health burden to the population.

A comparison of the level of dose intake by population from the three water sources show that the dose intake from treated water $>$ dose intake from bottled water > dose intake from tap water.

\section{CONCLUSIONS}

The study clearly indicates the most water of Jizan region to be free from any obvious pollution (according to national and international standards).

The gross alpha and beta activity concentrations in portable drinking water samples collected from the different areas in Jizan region were determined to investigate the radiological burden to the population. The data obtained can be used as a baseline for ascertaining possible changes in radioactivity concentrations in portable drinking water samples in this region. From the present work, it can be inferred that the drinking water samples from the study area have low radioactivity and all the results measured are below the World Health Organization, drinking water guideline values of 1.0 $\mathrm{Bq} / \mathrm{l}$ for the gross beta radioactivity, and value of $0.5 \mathrm{~Bq} / \mathrm{l}$ for gross alpha activity. Hence, the drinking water of the study area (Jizan, KSA.) is not radioactively contaminated, or rather is radioactively safe to use. 


\section{REFERENCES}

1. WHO 2011. Guidelines for Drinking Water Quality. 4th ed. Geneva, Switzerland: World Health Organization.

2. GSO (Gulf Standards organization) 2009. The second international workshop on guided-self organization, August 18-20. Max Planck Institute for Mathematics in the Sciences. http://www.mis.mpg.de/calendar/conferences/2009/gs09.html.

3. Pontius, F. W. 1990. Water Quality and Treatment. 4th Edition, McGraw-Hill Inc., New York.

4. Chatterjee, J., Chatterjee, C. 2000. Phytotoxicity of cobalt, chromium and copper in cauliflower. Environmental Pollution 109, 69-74.

5. Doğru, M., Külahcı, F. 2004. Iso-radioactivity curves of the water of the Hazar Lake, Elaziğ, Turkey. J. Radioanalytical and Nucl. Chem. 260, 557-562.

6. Tzortzis, M., Svoukis, E., Tsertos, H. 2004. A comprehensive study of natural gamma radioactivity levels and associated dose rates from surface soils in Cyprus. Radiat. Prot. Dosim. 109, 217-224.

7. Kawther, F. A., Suaad, S. A. 2007. Mineral and Microbial Contents of Bottled and Tap Water in Riyadh, Saudi Arabia. Middle-East J. of Scientific Res. 2 (3-4), 151-156.

8. Ahmad, M., Bajahlan, A. S. 1999. Quality comparison of tap water vs. bottled water in the industrial city of Yanbu (Saudi Arabia), Environ. Monit. Assess. 159, 1-14.

9. Alabdula'aly, A. I, Khan, M. A. 1999.,, Chemical composition of bottled water in Saudi Arabia. Environ. Monit. Assess. 54(2), 173-189.

10. Al-Omran, M. A., El-Maghraby, S. E., Aly, A. A., Al-Wabel, I. M., Al-Asmari, Z. A., Nadeem, M. E. 2012. Quality assessment of various bottled waters marketed in Saudi Arabia. Environ. Monit. Assess.185 (8), 6397-6406.

11. Al-Saleh, I., Al-Doush, I. 1998. Survey of trace elements in household and bottled drinking water samples collected in Riyadh, Saudi Arabia. Sci Total Environ. 216, 181-192.

12. Alabdula'aly, A. I. 1997. Fluoride content in drinking water supplies of Riyadh, Saudi Arabia. Environ. Monit. Assess. 48 (3), 261-272.

13. Alabdula'aly, A. I., Khan, M. A. 2009. Chemical Composition of Bottled Water in Saudi Arabia, Environ. Monit. Assess. 54, 173-189.

14. Aldrees, A. M., Al-Manea, S. A. 2010. Fluoride content of bottled drinking waters available in Riyadh, Saud Arabia. Saudi Dental J. 22, 189-193.

15. Khan, N. B., Chohan, A. N. 2010. Accuracy of bottled drinking water label content. Environ. Monit. Assess. 166 (1-4), 169-176.

16. Tayyeb, Z. A., Kinsara, A. R., Farid, S. M. 1998. A study on the radon concentration in water in Jeddah (Saudi Arabia) and the associated heath effects, J. Environ. Radioact. 38, 97-104.

17. Zahad, K., Mohamed, W. 2002. Quality of local and imported bottled water in Saudi Arabia, Eng. Sci. 14, 81-104.

18. Al-Mudhaf, H. F., Abu-Shady, A. S. I. 2012. Comparison of trace elements in bottled and desalinated household drinking water in Kuwait. CLEAN-Soil Air Water, 40, 986-1000.

19. Amin, Rafat M., Khalil, F. A., El Fayoumi, M. A. K. 2011. Natural radioactivity and chemical concentrations in Egyptian groundwater, Environ Monit Assess. 173, 29-35.

20. Baba, A., Erees, F. S., Hycsonmez, U, Cam, S., Ozdylek, H. G. 2008. An Assesment of the quality of various bottled mineral water marketed in Turkey. Environ Monit. Assess. 139, 277-285.

21. Özmen, H., Külahcı, F., Çukurovalı, A., Doğru, M. 2004. Concentrations of heavy metal and radioactivity in surface water and sediment of Hazar Lake, Elazığ, Turkey. Chemosphere 55, 401-408.

22. Turner, J.E. 1995. Atoms, Radiation and Radiation Protection, 2nd Ed. (John Wiley and Sons Ltd).

23. IAEA 2003. International Basic Safety Standards for Protection against lonizing Radiation and for the Safety of Radiation Sources, No. 115 (IAEA, Vienna,).

24. Ismail, A. M., Kullab, M. K., Saq'an, S. A. 2009. Natural Radionuclides in Bottled Drinking Water in Jordan and their Committed Effective Doses. Jordan, J. of Phys. 2(1), 47-57.

25. Fasae, K. P. 2013. Gross Alpha and Beta Activity Concentrations and Committed Effective dose due to intake of Groundwater in Ado-Ekiti Metropolis; the Capital City of Ekiti State, Southwestern, Nigeria. J. of Natural Sci. Res. 3(12), $61-66$.

26. Karamanisa, D. K., Stamoulisb, K. G. 2007. Natural radionuclides and heavy metals in bottled water in Greece. Desalination 213, 90-97. 
27. Bonotto, D. M., Bueno, T. O., Tessari, B.W., Silva, A. 2009. The natural radioactivity in water by gross alpha and beta measurements. Radiat. Meas. 44, 92 - 101.

28. Fasae, K. P. 2015. Gross Alpha and Beta Activity Concentrations in Portable Drinking Water in Ado - Ekiti Metropolis and the Committed Effective Dose. Intl. J. of Advanced Res. in Physical Sci. 2(1), 1-6.

29. Damla, N., Cevik, U., Karahan, G., Kobya, A. I., Kocak, M., Isik, U. 2009. Determination of gross alpha and beta activities in waters of Batman. Turkey, Desalination 244, $208-214$.

30. ICRP 1991. The 1990 Recommendations of the International Commission on Radiological Protection, Volume 21-23. Elsevier Health Sciences, USA. 